\title{
A One-Step, Immunochromatographic Lateral Flow Device Specific to Rhizoctonia solani and Certain Related Species, and Its Use to Detect and Quantify $R$. solani in Soil
}

\author{
Christopher R. Thornton, Andrew C. Groenhof, Robert Forrest, and Richard Lamotte
}

First author: School of Biological and Chemical Sciences, Washington Singer Laboratories, University of Exeter, Perry Road, Exeter, EX4 4QG, Devon, England, UK; second author: Eco Diagnostics Ltd., 23 Orchard Way, Kenton, Exeter, EX6 8JU, Devon, England, UK; and third and fourth authors: Alchemy Laboratories Ltd., Prospect 2, Dundee Technology Park, Dundee, DD2 1TY, Scotland, UK. Accepted for publication 9 November 2003.

\begin{abstract}
Thornton, C. R., Groenhof, A. C., Forrest, R., and Lamotte, R. 2004. A one-step, immunochromatographic lateral flow device specific to Rhizoctonia solani and certain related species, and its use to detect and quantify $R$. solani in soil. Phytopathology 94:280-288.

A murine hybridoma cell line GD2 secreting an immunoglobulin (Ig)M monoclonal antibody (MAb) was produced against surface antigens from an anastomosis group (AG) 4 isolate of Rhizoctonia solani (teleomorph: Thanatephorus cucumeris). Ascites were produced in mice using GD2 hybridoma cells and used to develop a rapid immunochromatographic lateral flow device (LFD) for the detection of antigens from $R$. solani and certain related Rhizoctonia spp. The LFD was tested for specificity against surface antigens from related and unrelated soil fungi. Antigens from representative isolates of $R$. solani AGs 1, 2-1, 2-3, 2-t, 3, 4, 5, 6, 7, $8,9,10,11$, and BI gave a positive response in LFD tests, as did antigens from Thanatephorus orchidicola, T. praticola, $R$. fragariae (teleomorph: Ceratorhiza fragariae), Ceratorhiza goodyerae-repentis, Ceratobasidium cornigerum, and binucleate AGE. Antigens from $R$. solani AGs 2-2, 22IIIB, and 2-2IV and from the related fungi $R$. carotae, $R$. cerealis

(teleomorph: Ceratobasium cereale), $R$. crocorum (teleomorph: Helicobasidium brebissonii), $R$. oryzae (teleomorph Waitea circinata), and $R$. zeae gave negative responses, as did antigens from a range of unrelated fungi and oomycetes including Fusarium, Gliocladium, Trichoderma, Pythium, and Phytophthora spp. The usefulness of the LFD to detect $R$. solani was demonstrated in soils naturally infested with $R$. solani AG3. There was close agreement between results of LFD tests and conventional plate enrichment tests employing selective medium. The specificity of the technique was confirmed by polymerase chain reaction PCR using $R$. solani AG3-specific primers and by analyses based on sequences of the internal transcribed spacer (ITS)1-5.8S-ITS2 rRNA-encoding regions of unrelated fungi recovered from soil samples. The LFD was used to quantify $R$. solani AG4 in artificially infested soil samples (chopped potato soil inoculum). Estimates of CFU per gram of soil were derived using a most-probable number technique, which was based on the presence or absence of a detectable signal in the LFD. Estimates of CFU obtained in LFD tests and those obtained in a plate-trapped antigen enzyme-linked immunosorbent assay incorporating MAb GD2 were identical (449 CFU g ${ }^{-1}$ of soil).
\end{abstract}

Rhizoctonia solani Kühn is a ubiquitous soilborne plant pathogen with worldwide distribution and broad host range, causing economically important diseases of vegetables, turf grasses, ornamentals, and fruit and forest trees $(1,2,25)$. The fungus is not a homogeneous species, but is composed of at least 12 anastomosis groups (AGs), AGs 1 to 12, and AGBI (25), varying in cultural morphology and pathogenicity.

Various techniques, involving baiting and culture plating, have been developed for the qualitative and quantitative detection of $R$. solani in soil $(15,31,34)$. Although effective, these methods require considerable taxonomic expertise because the selective media employed do not allow the discrimination of $R$. solani from other Rhizoctonia spp. or Rhizoctonia-like fungi frequently encountered under natural conditions. The advent of hybridoma technology allowed the production of specific monoclonal antibodies (MAbs) (10) and enabled the development of immunodiagnostic assays that detect actively growing mycelium of $R$. solani only, through a combination of nutrient enrichment or baiting and enzyme-linked immunosorbent assay (ELISA) (29,30). More recently, nucleic acid-based diagnostic techniques incorporating the polymerase chain reaction (PCR) and DNA probes have been used to detect and quantify the pathogen in naturally infested soil

Corresponding author: C. R. Thornton; E-mail address: C.R.Thornton@exeter.ac.uk

Publication no. P-2004-0112-02R

(C) 2004 The American Phytopathological Society samples and within infected roots $(6,7,35)$. Such techniques allow the detection of individual groups or subgroups of the pathogen $(6,7,21,35)$ but are unable to differentiate between actively growing, quiescent, and dead propagules of the fungus. Nevertheless, by incorporating a baiting step prior to PCR, Lees et al. (16) were able to develop a highly specific and sensitive test for the detection of live propagules of $R$. solani AG3 in soil.

Current ELISA and PCR tests for the detection of $R$. solani in soil are based largely in laboratories rehearsed in such techniques and which have access to specific antibodies or specialized equipment. A single-step test for the pathogen that could be performed by untrained personnel with limited access to laboratory facilities would significantly improve the availability of Rhizoctonia diagnostics to the wider scientific and agricultural end-user communities.

The purpose of this article is to report the development of a rapid and user-friendly immunochromatographic assay for $R$. solani and certain related Rhizoctonia spp. that can be used by untrained personnel. The aim was to produce a quick and easy diagnostic test that provided additional support for the rapid determination of the presence and absence of $R$. solani (and certain related Rhizoctonia spp.) in naturally infested soil samples. Once a sample is identified as a potential risk from infestation using the lateral flow device (LFD), additional tests can be performed to fully characterize the strains involved.

The assay exploits lateral flow technology that has been used, to date, in the manufacture of tests for the diagnosis of human 
diseases $(14,24)$, in the detection of contaminants in foodstuffs $(5,23,32,33)$, and in the detection of plant viruses (8). Traditionally, antibody-based diagnostic tests, such as the Alert flowthrough devices (18), have relied on enzyme reactions for the final visualization of results. To remove unbound enzyme, washing steps are necessary, thereby making the tests more time consuming. Enzymes can be replaced by binding antibodies to particulate labels, such as latex, colloidal gold, or silica. Using these labels, the detection of a target antigen is visualized when sufficient numbers of particles accumulate in one area, such as in slide agglutination tests. Alternatively, particles can be captured by antibodies immobilized to membranes in lines or dots. Specific antigens are "sandwiched" between the immobilized antibody and the antibody-sensitized particles and immune complexes. As the amount of captured antigen increases, the concentration of accumulated particles also increases and the reaction site becomes visible to the eye once a sufficiently high density is reached. This principle underlies all LFDs, rapid immunofilter paper assays (RIPAs), or immunochromatographic assays that employ particulate labels. The most famous use of this technology is the home pregnancy tests first introduced by Unipath in 1988.

Due to patent restrictions on the use of latex as a label, the LFD described here uses colloidal gold as the reporter molecule. Briefly, a MAb, which binds to an antigenic determinant (epitope) expressed by $R$. solani and certain related Rhizoctonia spp., is immobilized to a defined capture zone on a porous nitrocellulose membrane, while the same MAb conjugated to colloidal gold particles serves as the detection reagent. Samples of solubilized antigens are added to a release pad containing the antibody-gold conjugate. The antibody-gold conjugate binds to the target antigen, passes along the porous membrane by capillary action, and binds to the MAb immobilized in the capture zone. Once an antigen extract is prepared and applied to the LFD, the test result is recorded within $10 \mathrm{~min}$. Bound antigen-antibody-gold complex is seen as a red line with an intensity that is proportional to the antigen concentration. Anti-mouse immunoglobulin immobilized to the membrane in a separate zone acts as an internal control. In the absence of $R$. solani antigen, no complex is formed in the zone containing solid-phase antibody, and a single internal control line is seen. In the presence of $R$. solani antigens, two lines are clearly visible.

At present, there is a lack of effective control measures for soil infestations of plant-pathogenic fungi. Identification of sites at potential risk from infestation allows the grower to make betterinformed decisions with respect to disease evasion, particularly where specific strains of pathogens are associated with damage to particular crops. An example is $R$. solani AG3, which has been identified as the etiologic agent of stem canker and black scurf diseases in potato worldwide $(4,6,16)$. In this study, we show how lateral flow technology can be used in combination with other diagnostic procedures to help in the identification of sites infested with $R$. solani AG3. However, the LFD and principles employed in its use are applicable to other crops where diseases have been closely linked to individual Rhizoctonia spp. or AGs $(6,7,12$, $13,21,22,35,37)$.

\section{MATERIALS AND METHODS}

Fungal culture. Details of fungi and oomycetes used in this study are shown in Table 1. All isolates with the exception of Pythium spp., which were grown on cornmeal agar (CMA), were maintained on potato dextrose agar (PDA). Rhizoctonia spp. are referred to throughout the text as their anamorphic states.

Development of MAbs, preparation of immunogen, and immunization regime. MAbs were raised against an AG4 isolate (AB1) of $R$. solani causing damping-off disease in a wide range of hosts and bottom rot of lettuce (30). An AG4 isolate was selected for antibody development because this group has been shown in previous studies $(29,30)$ to share common antigens and epitopes with other AGs. By raising MAbs to this AG, the likelihood of developing a genus-specific antibody was improved significantly. The fungus was grown as a PDA slope culture for 5 days at $23^{\circ} \mathrm{C}$ and surface washings prepared in $2 \mathrm{ml}$ of phosphatebuffered saline (PBS; $0.8 \% \mathrm{NaCl}, 0.02 \% \mathrm{KCl}, 0.115 \% \mathrm{Na}_{2} \mathrm{HPO}_{4}$, $0.02 \% \mathrm{KH}_{2} \mathrm{PO}_{4}, \mathrm{pH} 7.2$ ) (28). Cellular debris were precipitated by centrifugation at $12,000 \times g$ for $5 \mathrm{~min}$ and the supernatant diluted 1:10 in fresh PBS. This solution was used as the immunogen. Three 6-week-old BALB/c female white mice each were given four intraperitoneal injections ( $300 \mu \mathrm{l}$ per injection) of fresh immunogen at 2-week intervals and a single booster injection 5 days before fusion.

Production and screening of hybridomas. Hybridoma cells were produced by the method described by Dewey (9) and the supernatants were screened by plate-trapped antigen (PTA)ELISA as described in the proceeding section. Primary screening was performed against the immunogen. Secondary screening for specificity was performed against 1/10-strength surface washings prepared from 5-day-old slope cultures of Fusarium solani f. sp. pisi, Pythium ultimum var. ultimum, and Trichoderma viride (Table 1) grown at $23^{\circ} \mathrm{C}$ on respective agars. Microtiter wells arranged in strips (9502037; Labsystems Oy, Helsinki, Finland) were coated overnight at $4{ }^{\circ} \mathrm{C}$ with 50 - $\mu$ l volumes of $1 / 10$-strength surface washings. The wells were washed four times with PBS plus $0.05 \%$ (vol/vol) Tween 20 (polyoxyethylene-sorbitan monolaurate) (PBST) (P1379; Sigma Chemical Co., Poole, Dorset, England) and once each with $\mathrm{PBS}$ and $\mathrm{dH}_{2} \mathrm{O}$ and air dried at $23^{\circ} \mathrm{C}$ in a laminar flow hood. The strips were stored in sealed plastic bags at $4^{\circ} \mathrm{C}$ in preparation for testing by PTA-ELISA.

PTA-ELISA. Wells containing immobilized surface antigens were incubated successively with hybridoma supernatant for $1 \mathrm{~h}$ and then by goat anti-mouse polyvalent (immunoglobulin [Ig] classes G, A, and M) peroxidase conjugate (A0412; Sigma) diluted 1:1000 in PBST for a further hour. Bound antibody was visualized by incubating wells with tetramethyl benzidine (TMB) substrate solution for $30 \mathrm{~min}$, reactions were stopped by the addition of $3 \mathrm{M} \mathrm{H}_{2} \mathrm{SO}_{4}$, and absorbance values were determined at $450 \mathrm{~nm}$ with an MRX automated microplate reader (Dynex Technologies, England). Wells were given four 5-min rinses with PBST between incubations. Working volumes were $50 \mu \mathrm{l} /$ well and control wells were incubated with tissue culture medium (TCM) containing $10 \%$ (vol/vol) fetal calf serum. All incubation steps were performed at $23^{\circ} \mathrm{C}$ in sealed plastic bags.

Determination of Ig subclass and cloning procedure. The Ig subclass of MAbs was determined with a commercial mouse MAb-isotyping kit according to the manufacturer's instructions (ISO-1; Sigma). Hybridoma cells lines were cloned by limiting dilution, and cell lines were grown in bulk in a nonselective medium, preserved by slowly freezing in fetal bovine serum/ dimethyl sulfoxide $(92: 8, \mathrm{vol} / \mathrm{vol})$, and maintained in liquid nitrogen.

Production of ascites fluid. Ascites fluid was prepared from hybridoma cells in female BALB/c mice (Eurogentec s.a., Belgium). Three pristanized mice each were injected with $2 \times$ $10^{6}$ hybridoma cells washed in PBS. After 3 weeks, approximately $5 \mathrm{ml}$ of ascites fluid was recovered from each mouse. The ascites was filtered through glass wool to remove coagulated material, sodium azide was added $(0.02 \%$, wt/vol) as a preservative, and the fluid stored at $-20^{\circ} \mathrm{C}$ prior to use.

Configuration of the LFD. The LFD consisted of G\&L Diecut 1734 backing card, Whatman $17 \mathrm{chr}$ and 1281 top and sample pads, respectively, and Whatman Immunopore 5- $\mu \mathrm{m}$ nitrocellulose membrane. The GD2 Ig in ascites fluid was conjugated to $40-\mathrm{nm}$ gold particles, applied to the release pad at 100 units of conjugate $\mathrm{cm}^{-1}$, and dried for $16 \mathrm{~h}$ at $37^{\circ} \mathrm{C}$. Test line antibody consisted of GD2 ascites at $0.5 \mathrm{mg}$ of protein $\mathrm{ml}^{-1}$ of PBS con- 
taining $1 \%(\mathrm{wt} / \mathrm{vol})$ bovine serum albumin while a commercial anti-mouse Ig acted as the control line.

Sensitivity and specificity of the LFD. Sensitivity of the LFD was tested using surface washings from $R$. solani AB1. This solution acted as the antigen standard in all tests. Sensitivity was determined using serial dilutions of the standard. Specificity of the LFD was determined with surface washings prepared from related and unrelated fungi. All solutions were adjusted with PBS

TABLE 1. Details of fungal and oomycete cultures and results (positive or negative) of lateral flow device (LFD) tests of surface washings

\begin{tabular}{|c|c|c|c|}
\hline Organism & Isolate no. & Source $^{a}$ & Test results \\
\hline Aspergillus malignus & 123.62 & CBS & - \\
\hline \multirow[t]{4}{*}{ Ceratobasidium cornigerum } & 34054 & ATCC & + \\
\hline & 132.82 & CBS & + \\
\hline & 476.82 & CBS & + \\
\hline & 570.62 & CBS & + \\
\hline Ceratorhiza goodyerae-repentis & 90459 & ATCC & + \\
\hline Chaetomium sp. ${ }^{\mathrm{b}}$ & BAN12/A7 (AY247558) & CRT & - \\
\hline Fusarium culmorum $^{\mathrm{b}}$ & BAN12/A2 (AY247556) & CRT & - \\
\hline F. oxysporum f. sp. pisi & 260.50 & CBS & - \\
\hline F. oxysporum f. sp. vasinfectum ${ }^{\text {b }}$ & BAN12/B2 (AY247553) & CRT & - \\
\hline F. solani f. sp. pisi & 231.34 & CBS & - \\
\hline Gaeumannomyces graminis var. tritici & $16 / 8$ & GLB & - \\
\hline Gliocladium roseum & 710.86 & CBS & - \\
\hline G. viride & 228.48 & CBS & - \\
\hline Mucor hiemalis f. sp. corticolus & 534.78 & CBS & - \\
\hline M. circinelloides $^{\mathrm{b}}$ & BAN12/A5 (AY247555) & CRT & - \\
\hline M. racemosus ${ }^{\mathrm{b}}$ & BAN12/B1 (AY247554) & CRT & - \\
\hline Penicillium expansum & 230.38 & CBS & - \\
\hline Phialophora hyalina & 130.74 & CBS & - \\
\hline Pythium debaryanum & 752.96 & CBS & - \\
\hline P. irregulare & 287.31 & CBS & - \\
\hline P. oligandrum & 530.74 & CBS & - \\
\hline P. ultimum var. ultimum & 296.37 & CBS & - \\
\hline P. sylvaticum & 227.68 & CBS & - \\
\hline \multirow[t]{4}{*}{ Rhizoctonia carotae } & 464.48 & CBS & - \\
\hline & 311.78 & CBS & - \\
\hline & 746.84 & CBS & - \\
\hline & 768256 & IMI & - \\
\hline \multirow[t]{17}{*}{ R. cerealis } & M41 & $\mathrm{PN}$ & - \\
\hline & M42 & $\mathrm{PN}$ & - \\
\hline & $\mathrm{R} 83 / 260$ & PN & - \\
\hline & $\mathrm{SL} 3 / 2$ & $\mathrm{PN}$ & - \\
\hline & SL3/3 & PN & - \\
\hline & SL4/1 & PN & - \\
\hline & SL4/2 & PN & - \\
\hline & SL6/3 & PN & - \\
\hline & SL8/2 & PN & - \\
\hline & $\mathrm{ES} 1 / 2$ & PN & - \\
\hline & $\mathrm{R} 82 / 261$ & PN & - \\
\hline & $\mathrm{R} 83 / 260$ & PN & - \\
\hline & $\mathrm{R} 84 / 280$ & PN & - \\
\hline & 570.83 & CBS & - \\
\hline & 558.77 & CBS & - \\
\hline & 559.77 & CBS & - \\
\hline & 560.77 & CBS & - \\
\hline \multirow[t]{4}{*}{ R. crocorum } & 162.24 & CBS & - \\
\hline & 163.24 & CBS & - \\
\hline & 324.67 & CBS & - \\
\hline & 38720 & CBS & - \\
\hline R. fragariae & 335.62 & CBS & + \\
\hline \multirow{10}{*}{$R$. oryzae } & 273.38 & CBS & - \\
\hline & 472.82 & CBS & - \\
\hline & 473.82 & CBS & - \\
\hline & 375117 & IMI & - \\
\hline & 375118 & IMI & - \\
\hline & 375119 & IMI & - \\
\hline & 375120 & IMI & - \\
\hline & 375121 & IMI & - \\
\hline & 375125 & IMI & - \\
\hline & 376335 & IMI & - \\
\hline
\end{tabular}

(continued on next page)

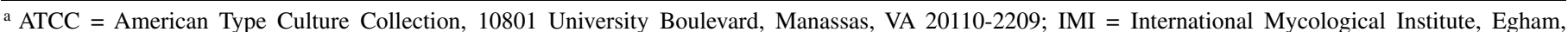
England; IPO = Institute voor Planteziektenk, Onderzoek, Wageningen, the Netherlands; GLB = G. L. Bateman, Institute of Arable Crops Research Experimental Station, Harpenden, England; PN = P. Nicholson, Cambridge Laboratory, John Innes Centre for Plant Science Research, Norwich, England; CBS = Centraalbureau voor Schimmelcultures, PO Box 85167, 3508 AD Utrecht, The Netherlands; CRT = C. R. Thornton; MUCL = Mycotheque de l'Universite catholique de Louvain, Place Croix du Sud 3, B-1348 Louvain-la-Neuve, Belgium.

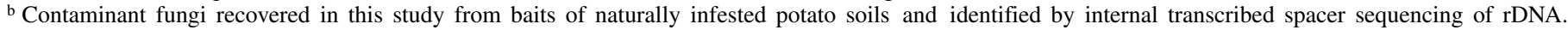
GenBank accession numbers are shown in parentheses.

c $\mathrm{AG}=$ anastomosis group. 
to contain the same protein concentration $\left(6 \mu \mathrm{g} \mathrm{ml}^{-1}\right)$ as the undiluted standard (determined using the Bio-Rad Bradford protein assay). Solution $(100 \mu \mathrm{l})$ was applied to the LFD and the results recorded $10 \mathrm{~min}$ after application. Results were recorded as posi- tive for the presence of $R$. solani antigens (two lines) or negative (single control line only).

Quantification of $R$. solani in artificially infested soil. Chopped potato-soil (CPS) inoculum (29) was prepared from $R$.

TABLE 1. (continued from preceding page)

\begin{tabular}{|c|c|c|c|}
\hline Organism & Isolate no. & Source $^{\mathrm{a}}$ & Test results \\
\hline \multicolumn{4}{|l|}{ R. solani $\mathrm{AG}^{\mathrm{c}}$} \\
\hline \multirow[t]{4}{*}{1} & 01R01 & IPO & + \\
\hline & 01R02 & IPO & + \\
\hline & 01R03 & IPO & + \\
\hline & USDA1 & USDA & + \\
\hline \multirow[t]{5}{*}{$2-1$} & 21R01 & IPO & + \\
\hline & 21R06 & IPO & + \\
\hline & 21R31 & IPO & + \\
\hline & 21R41 & IPO & + \\
\hline & 21R71 & IPO & + \\
\hline \multirow[t]{4}{*}{$2-2$} & 22R11 & IPO & - \\
\hline & 22R20 & IPO & - \\
\hline & 209.84 & CBS & - \\
\hline & 210.84 & CBS & - \\
\hline 2-2IIIB & 101765 & CBS & - \\
\hline 2-2IV & 101767 & CBS & - \\
\hline \multirow[t]{4}{*}{$2-3$} & 101768 & CBS & + \\
\hline & 23R01 & IPO & + \\
\hline & 23R02 & IPO & + \\
\hline & $23 \mathrm{R} 03$ & IPO & + \\
\hline \multirow[t]{4}{*}{$2 \mathrm{~T}$} & 2tR118 & IPO & + \\
\hline & $2 \mathrm{tR} 123$ & IPO & + \\
\hline & $2 \mathrm{tR} 130$ & IPO & + \\
\hline & $2 \mathrm{tR} 142$ & IPO & + \\
\hline \multirow[t]{4}{*}{3} & 03R01 & IPO & + \\
\hline & 163.82 & CBS & + \\
\hline & 324.68 & CBS & + \\
\hline & 303158 & IMI & + \\
\hline \multirow[t]{5}{*}{4} & AB1 & CRT & + \\
\hline & 303162 & IMI & + \\
\hline & 04R02 & IPO & + \\
\hline & $04 \mathrm{R} 03$ & IPO & + \\
\hline & $04 \mathrm{R} 22$ & IPO & + \\
\hline \multirow[t]{4}{*}{5} & 303159 & IMI & + \\
\hline & $05 \mathrm{R} 01$ & IPO & + \\
\hline & 159.83 & CBS & + \\
\hline & 161.83 & CBS & + \\
\hline \multirow[t]{4}{*}{6} & 06R01 & IPO & + \\
\hline & $06 \mathrm{R} 02$ & IPO & + \\
\hline & 594.81 & CBS & + \\
\hline & 303160 & IMI & + \\
\hline \multirow[t]{2}{*}{7} & 303161 & IMI & + \\
\hline & 214.84 & CBS & + \\
\hline \multirow[t]{2}{*}{8} & 101781 & CBS & + \\
\hline & 101782 & CBS & + \\
\hline 9 & 969.96 & CBS & + \\
\hline & 970.96 & CBS & + \\
\hline & 09R01 & IPO & + \\
\hline 10 & 971.96 & CBS & + \\
\hline & 594.82 & CBS & + \\
\hline 11 & 973.96 & CBS & + \\
\hline & 974.96 & CBS & + \\
\hline $\mathrm{BI}$ & BIR01 & IPO & + \\
\hline Rhizoctonia AGE & 342.84 & CBS & + \\
\hline R. zeae & 384.34 & CBS & - \\
\hline Rhizopus stolonifer & 807.83 & CBS & - \\
\hline Stachybotrys chartarum & 485.48 & CBS & - \\
\hline Thanatephorus orchidicola & 24752 & ATCC & + \\
\hline T. praticola & 348.87 & IMI & + \\
\hline & 340.51 & CBS & + \\
\hline Trichoderma hamatum & GOD-B4 & CRT & - \\
\hline T. hamatum ${ }^{\mathrm{b}}$ & BAN12/B3 (AY247559) & CRT & - \\
\hline T. harzianum & LEV-A8 & CRT & - \\
\hline T. koningii & TLS & CRT & - \\
\hline T. virens & 625.76 & CBS & - \\
\hline T. viride & HBC-B4 & CRT & - \\
\hline Tulasnella calospora & 573.83 & CBS & - \\
\hline T. irregularis & 574.83 & CBS & - \\
\hline Verticillium coccosporum $^{\mathrm{b}}$ & BAN2/B8 (AY247557) & CRT & - \\
\hline V. dahliae & 800.97 & CBS & - \\
\hline
\end{tabular}


solani AB1 using a loam soil (loamy sand; clay content $6.85 \%$, organic matter content $1.1 \%$, and cation exchange capacity of $7.7 \mathrm{meq} / 100 \mathrm{~g} ; \mathrm{pH}-\mathrm{H}_{2} \mathrm{O}$ 6.7). Quantification of $R$. solani in the inoculum was determined by quantal assay based on the mostprobable number of CFU per gram of soil (11). Inoculum particles 250 to $500 \mu \mathrm{m}$ in size were double diluted with sand of the same particle size to give a dilution series ranging from undiluted inoculum to a 1 in 4,096 dilution of CPS. Five replicate 1 -g samples from each dilution of inoculum were placed in $25-\mathrm{ml}$ polyvials containing $2 \mathrm{ml}$ of amplification solution (AS) consisting of, per liter of $\mathrm{dH}_{2} \mathrm{O}, 1 \mathrm{~g}$ of $\mathrm{K}_{2} \mathrm{HPO}_{4}, 0.5 \mathrm{~g}$ of $\mathrm{MgSO}_{4}-7 \mathrm{H}_{2} \mathrm{O}$, $0.5 \mathrm{~g}$ of $\mathrm{KCl}, 0.2 \mathrm{~g}$ of $\mathrm{NaNO}_{2}, 0.4 \mathrm{~g}$ of gallic acid, $5 \mathrm{~g}$ of potato starch, $10 \mathrm{mg}$ of $\mathrm{FeSO}_{4}-7 \mathrm{H}_{2} \mathrm{O}, 50 \mathrm{mg}$ each of chloramphenicol and streptomycin sulfate, and propamocarb (Fluka, Buchs, Switzerland) at $20 \mathrm{ppm}$. The medium was autoclaved for $15 \mathrm{~min}$ at $121{ }^{\circ} \mathrm{C}$ prior to addition of the antibiotics. The tubes were incubated with gentle mixing for $72 \mathrm{~h}$ at $23^{\circ} \mathrm{C}$, the contents centrifuged at $12,000 \times g$ for $5 \mathrm{~min}$, and samples tested for the presence of $R$. solani antigen by LFD. Supernatant $(100 \mu \mathrm{l})$ was applied to the LFD and results recorded as positive or negative for $R$. solani antigens as described. Quantification of $R$. solani by LFD was compared with estimates of inoculum density determined in a conventional PTA-ELISA. Fifty-microliter samples of supernatant were added to the wells of microtiter strips. Immobilization of antigens and washing of strip were as described. For the PTAELISA, wells were blocked for 10 min with Tris-buffered saline containing $0.3 \%$ (wt/vol) casein (TBS/c; $8 \mathrm{~g}$ of NaCl, $3 \mathrm{~g}$ of Tris, and $0.2 \mathrm{~g}$ of $\mathrm{KCl}$ per liter of $\mathrm{dH}_{2} \mathrm{O}$, adjusted to $\mathrm{pH} 8.3$ with $1 \mathrm{~N} \mathrm{HCl}$ ) and then incubated sequentially with GD2 MAb supernatant for $1 \mathrm{~h}$ and with goat anti-mouse polyvalent (classes IgG, IgA, and IgM) peroxidase conjugate (A0412; Sigma) diluted 1:1000 in TBS/c for a further hour. Bound antibody was visualized by incubating wells with TMB substrate solution for $30 \mathrm{~min}$, reactions were stopped by the addition of $3 \mathrm{M} \mathrm{H}_{2} \mathrm{SO}_{4}$, and absorbance values were determined at $450 \mathrm{~nm}$ with an MRX automated microplate reader (Dynex Technologies, Billingshurst, UK). Wells were given four 5-min rinses with TBS/c between incubations and were given a final rinse with $\mathrm{dH}_{2} \mathrm{O}$ prior to the substrate. All incubation steps were performed at $23^{\circ} \mathrm{C}$ in sealed plastic bags. The positive-negative threshold value for detection of $R$. solani antigens in the PTA-ELISA was established from the mean absorbance value of the highest dilution $(1: 4,096)$ of CPS (11). Because of the very low background levels in the PTAELISA $(<0.100$ absorbance unit), an arbitrary threshold value of 0.100 also was used for comparison (27). Estimates of the most probable number of CFU per gram of undiluted inoculum obtained using the dilution procedure were determined in Genstat (20).

Detection of $\boldsymbol{R}$. solani in naturally infested soil. Soil samples were obtained in June 2002 from a field (Great Down, Thorverton, Devon, UK) used for potato production that had experienced stem canker and black scurf disease in the 2000 and 2001 growing seasons. Five random subsamples were taken from the top $10 \mathrm{~cm}$ of soil at each of two sites, BAN1 and BAN12 (grid references 292317/100216 and 292368/100416, respectively). The subsamples at each site were pooled. The baiting technique described by Thornton et al. (30) was used to isolate $R$. solani and other fungi. For each site, there was a single baiting module consisting of two replicate dishes A and B. After incubation at $23^{\circ} \mathrm{C}$ for $72 \mathrm{~h}$, seed baits were transferred to 5 -cm petri dishes containing semiselective medium consisting of AS without starch but with $2 \%$ (wt/vol) agar. After incubation at $23^{\circ} \mathrm{C}$ for $48 \mathrm{~h}$, cultures were examined for putative $R$. solani isolates according to vegetative characteristics (19). All fungi were subcultured onto PDA containing the antibiotic rifampicin (R3501; Sigma) at $100 \mu \mathrm{g} \mathrm{ml}^{-1}$ and antigen extracts prepared from the original bait cultures by washing colonies in $1 \mathrm{ml}$ of PBS with a glass loop. Surface washings were centrifuged at $12,000 \times g$ for $5 \mathrm{~min}$ and $100 \mu \mathrm{l}$ of supernatant was tested in the LFD for $R$. solani antigens as described. The AG of putative $R$. solani isolates was determined by PCR using published primers $(6,16)$. Fungi other than $R$. solani were classified to species level by sequencing the internal transcribed spacer (ITS) region of the rRNA-encoding gene unit. Representative isolates of contaminant fungi were grown in axenic culture and surface washings assayed for positive or negative responses in LFD tests as described.

Determination of $R$. solani AG by PCR and identification of contaminant fungi by analysis of the nuclear ITS regions of the ribosomal RNA encoding gene unit. The $R$. solani AG3specific PCR methods of Bounou et al. (6) and Lees et al. (16) were used to identify putative $R$. solani isolates. Contaminant fungi were identified to species level by amplification of ribosomal RNA-encoding genes using a modification of the method described by Sreenivasaprasad et al. (26). The extended primers ITS1ext (5'-GTAACAAGGTTTCCGTAGGTG-3') and ITS4ext (5'-TTCTTTTCCTCCGCTTATTGATATGC-3') were used to amplify both ITS regions and the $5.8 \mathrm{~S}$ gene of the ribosomal RNA encoding gene unit. These were provided by MWG Biotech AG (Ebersberg, Germany) and their sequences based on those described by White et al. (36). The PCR reactions were performed as follows. Approximately 10 to $25 \mathrm{ng}$ of genomic DNA was added to a $0.2-\mathrm{ml}$ Eppendorf tube, prechilled to $-20^{\circ} \mathrm{C}$, containing $0.05 \mu \mathrm{M}$ primer, $2 \mathrm{mM}$ (each) dATP, dCTP, dGTP, and dTTP (Pharmacia), 0.25 units of Taq polymerase (Promega), 1× Taq polymerase buffer (Promega), and $2 \mathrm{mM} \mathrm{MgCl}_{2}$ (Promega). The final reaction volume was $25 \mu \mathrm{l}$. PCR amplification was performed in a thermal cycler (Hybaid Omn-E) using the following cycling conditions: $2 \mathrm{~min}$ at $94^{\circ} \mathrm{C} ; 35$ cycles at $94^{\circ} \mathrm{C}$ for $1 \mathrm{~min}$, $55^{\circ} \mathrm{C}$ for $1 \mathrm{~min}$, and $72^{\circ} \mathrm{C}$ for $3 \mathrm{~min}$; and a final extension of $5 \mathrm{~min}$ at $72^{\circ} \mathrm{C}$. Reaction products were fractionated using a $1.6 \%$ (wt/vol) agarose gel. DNA fragments were purified from gels using a commercial kit (GENECLEAN; BIO 101 Inc., Palo Alto, $\mathrm{CA}$ ) according to the manufacturer's instructions. The entire ITS1-5.8S rRNA-ITS2 region was sequenced in both strands. Dye-labeled terminator cycle sequencing was performed on a Long ReadIR 4200 DNA sequencer (Li-Cor Biosciences, UK, Ltd.) using the nested primers ITS1 (5'-TCCGTAGGTGAACCTGCGG-3') and ITS4 (5'-TCCTCCGCTTATTGATATGC$\left.3^{\prime}\right)$. Double-stranded DNA sequences were aligned using DNA Strider 1.1 (17) and Sequence Navigator 1.0.1 (Perkin-Elmer). The gapped Blast program 2.0 (3) was used to compare nucleic acid sequences with those contained within databases held at the NCBI. Species identity was predicted based on $>95 \%$ sequence identity (E-value $=0.0)(3)$ of the ITS1-5.8S-ITS2 region of contaminant species to species recorded in GenBank. The ITS sequences of representative isolates of contaminant fungi were submitted to GenBank and accession numbers obtained.

\section{RESULTS}

Screening of hybridoma cell lines, isotyping, and ascites production. A single fusion was performed. From this, 243 hybridoma cell lines were screened for MAb production, and 162 tested positive for recognition of the immunogen. One of these (MAb GD2) was selected for further testing on the basis of absorbance value (absorbance at $450 \mathrm{~nm}\left[A_{450}\right]>1.500$ ). In PTAELISA tests, MAb GD2 reacted strongly with surface antigens from $R$. solani $\mathrm{AB} 1$ but did not crossreact with surface antigens from $F$. solani f. sp. pisi, P. ultimum var. ultimum, or T. viride. In all three cases, absorbance values were $<0.100$. The MAb from the subcloned cell line GD2 was from Ig class M. Ascites from the cell line GD2 contained protein at $15.88 \mathrm{mg} \mathrm{ml}^{-1}$ of fluid.

Sensitivity and specificity of the LFD. The limit of detection of the standard antigen solution in the LFD was 1:20,000, corresponding to protein at $3 \mathrm{ng} \mathrm{ml}^{-1}$ of buffer. In specificity tests, a positive LFD response was recorded with surface antigens from 
$R$. solani AGs 1, 2-1, 2-3, 2-t, 3, 4, 5, 6, 7, 8, 9, 10, 11, BI, binucleate Rhizoctonia AGE, Thanatephorus praticola, $R$. fragariae, and Ceratobasidium cornigerum (Fig. 1A and B). A negative response was recorded with antigens from $R$. solani AGs 2-2, 2-2IIIB, and 2-2IV and from the related fungi $R$. carotae, $R$. cerealis, $R$. crocorum, $R$. oryzae (Fig. $1 \mathrm{~A}$ and $\mathrm{B}$ ), and $R$. zeae and with antigens from a range of unrelated fungi and oomycetes, including Fusarium, Gliocladium, Trichoderma, Pythium, and Phytophthora spp. (Table 1). Other fungi that were recovered from baits during tests of naturally infested soils also gave a negative response with the LFD (Table 1).

Quantification of $\boldsymbol{R}$. solani in artificially infested soil. The positive-negative threshold in the PTA-ELISA was established from the mean absorbance value of the highest dilution $(1: 4,096)$ of CPS (Table 2). Consequently, any values of $>0.046$ were scored as positive for $R$. solani antigens, with values of $<0.046$ treated as negative. Using this threshold value, the most probable number of colony-forming units per gram of undiluted CPS
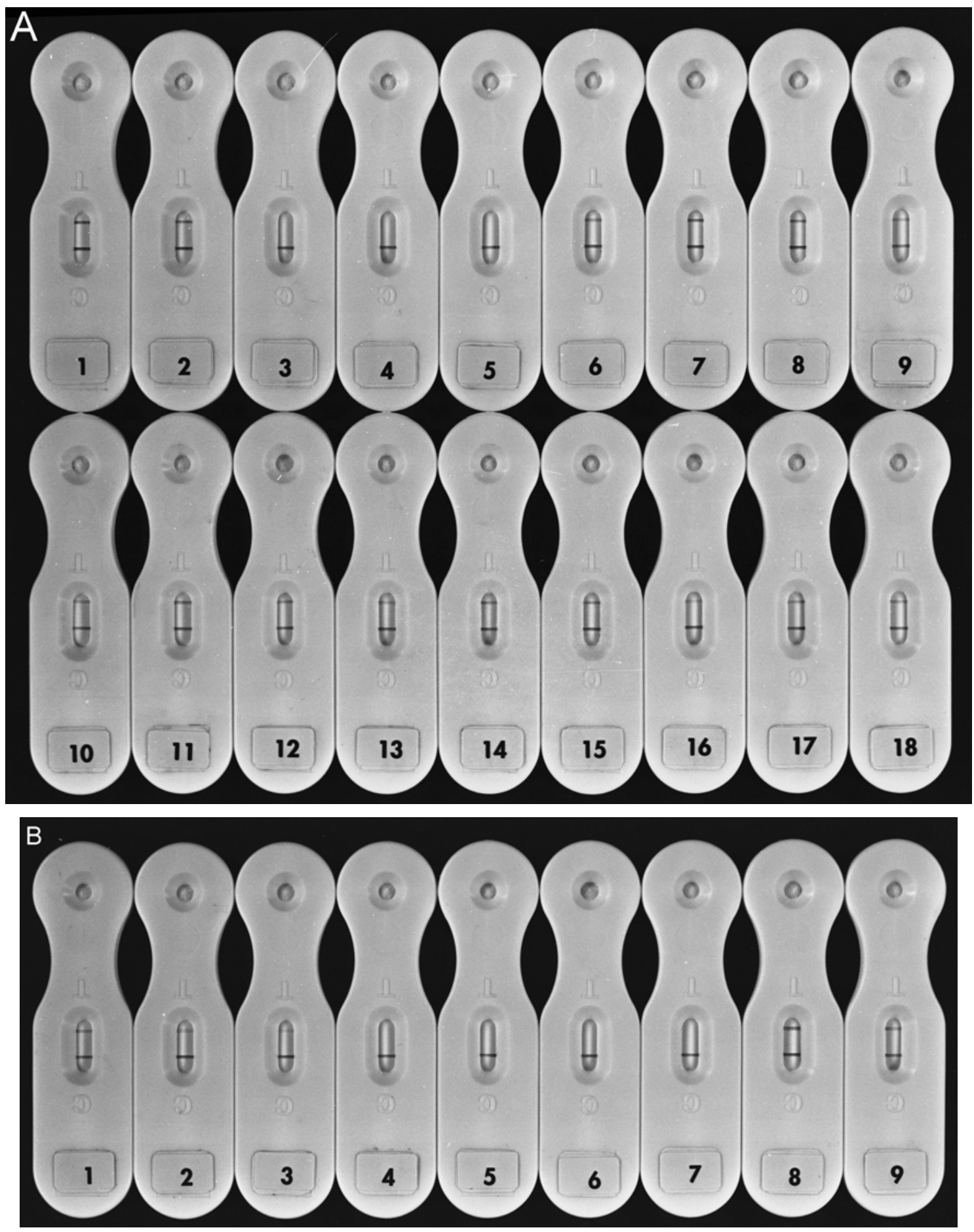

Fig. 1. Examples of positive (two lines) and negative (single control line) responses in lateral flow device tests with surface washings from A, Rhizoctonia solani anastomosis groups (AGs) (isolates are given in parentheses). 1, AG1 (01R01); 2, AG2-1 (21R06); 3, AG2-2 (210.84); 4, AG2-2IIIB (101765); 5, AG2-2IV (101767); 6, AG2-3 (101768); 7, AG2t (2tR002); 8, AG3 (USDA3); 9, AG4 (AB1); 10, AG5 (159.83); 11, AG6 (594.81); 12, AG7 (214.84); 13, AG8 (101782); 14, AG9 (969.96); 15, AG10 (971.96); 16, AG11 (973.96); 17, AGBI (BIR01); 18, binucleate Rhizoctonia AGE (342.84). B, Related Rhizoctonia spp. 1, Ceratobasidium cornigerum (340.54); 2, R. fragariae (335.62); 3, Ceratorhiza goodyerae-repentis (90459); 4, R. carotae (746.84); 5, R. cerealis (236.77); 6, $R$. crocorum (162.24); 7, R. oryzae (273.38); 8, Thanatephorus orchidicola (24752); 9, T. praticola (340.57). 
inoculum was estimated to be $449 \mathrm{CFU} \mathrm{g}^{-1}$, with fiducial limits ( $\alpha=0.05$ ) of 236 to 819 in both the LFD and PTA-ELISA tests. When an arbitrary positive-negative threshold of 0.100 was employed, the estimates were $449 \mathrm{CFUs}^{-1}$ (fiducial limits of 236 to 819 ) in the LFD test and 388.2 (fiducial limits of 205 to 707) in the PTA-ELISA.

Detection of $R$. solani AG3 in naturally infested soil and identification of contaminant fungi by ITS sequencing. A combined baiting-LFD procedure was used to detect the pathogen in two soils that had histories of infestation by $R$. solani AG3 pathogenic to potatoes. Based on visual assessment of bait cultures, $R$. solani was present in replicate samples from both soils. The presence of the pathogen was confirmed by LFD tests of surface washings of fungal colonies. Discrepancies were observed between the two tests at the pseudoreplicate (individual seed) level (Table 3). In these cases, overgrowth by faster-growing contaminant species prevented rapid growth of $R$. solani hyphae that could be seen emerging from baits. Using PCR, $R$. solani isolates that were recovered were shown to belong to AG3. Isolates of contaminant fungi were identified to species level by comparison of their rRNA encoding regions with nucleic acid sequences contained within databases held at the NCBI website (Table 3). Identity was predicted based on $>95 \%$ sequence identity (E-value $=$ 0.0) (3) of the ITS1-5.8S-ITS2 region of contaminant species to species recorded in GenBank. Using this procedure, contaminant fungi were shown to belong to five genera of Ascomycete and Zygomycete fungi, namely Chaetomium sp., F. culmorum, F. oxysporum f. sp. vasinfectum, Mucor racemosus, $M$. circinelloides, Trichoderma hamatum, and Verticillium coccosporum (Tables 1 and 3). Surface washings from axenic cultures of $R$. solani isolates recovered from baits gave positive responses in LFD tests, while surface washings from contaminant species all gave negative responses. Results of these tests, identities of contaminant species, and their accession numbers are shown in Table 1.

\section{DISCUSSION}

A murine $\operatorname{IgM}$ MAb was raised against surface antigens from an AG4 isolate of $R$. solani. Although MAbs have been raised to $R$. solani in a previous investigation (29), intellectual property issues prevented their use in this study. MAb GD2 described here, which binds to an epitope of a constitutive, extracellular antigen produced by live propagules of $R$. solani and certain related species, was used to develop a one-step LFD for the detection and quantification of live propagules of the pathogen (and certain related species) in naturally and artificially infested soil samples. This was achieved using a combined baiting procedure or by incubating soil samples in an amplification solution to stimulate growth of mycelium and antigen production. This is the first time, to our knowledge, that an LFD has been devel- oped and tested in vivo for the diagnosis of a soilborne plantpathogenic fungus.

Although the LFD test described here is at the prototype stage, we believe we have demonstrated the potential of lateral-flow technology in the detection of a fungal plant pathogen in soil. Furthermore, we have shown how such a test can be used to quantify inoculum densities in artificially infested soil samples using a simple quantal assay that allows estimates of CFU to be determined. Comparison of the LFD test with a conventional PTA-ELISA showed that the LFD exhibited equivalent sensitivity in detecting the target antigen. Although inoculum densities in soil are likely to be different for each AG, this technique is applicable to all Rhizoctonia spp. and AGs recognized by the LFD.

Antibody-based flow-through tests are available for the detection of several plant pathogens, including Phytophthora, Pythium, and Rhizoctonia spp. These Alert kits are relatively sophisticated, involving a number of reagent and wash steps following the application of antigen extracts $(8,18)$. Furthermore, the Rhizoctonia Alert test does not discriminate between $R$. solani and $R$. cerealis and also reacts weakly with antigens from $R$. oryzae and $R$. zeae. The LFD described here involves a single step and does not react with antigens from $R$. cerealis, $R$. oryzae, $R$. carotae, $R$. crocorum, or $R$. zeae. Nevertheless, positive reactions were exhibited with antigens from Ceratobasidium cornigerum and $R$. fragariae and from the orchid endophytes Ceratorhiza goodyerae-repentis and Thanatephorus orchidicola. However, we have not encountered these fungi during extensive tests of agricultural and horticultural soils in the United Kingdom and, therefore, do not regard them as problematic in the detection of $R$. solani in soil in this country. Further tests are required with soil samples from countries other than the United Kingdom to determine the level of interference from fungi such as Ceratobasidium sp.

It is important to note that the LFD was developed as an aid to complement other diagnostic procedures. Its ease of use by untrained personnel enables the simple identification of sites at potential risk from infestation by $R$. solani. While the LFD detects other related species, isolates detected and recovered using the procedure described can be identified subsequently to species or AG level using more sophisticated techniques such as PCR that employ specific primers $(6,7,12,21,35)$. Notwithstanding this, anamorphic Rhizoctonia spp., with teleomorphs in multinucleate Thanatephorus and binucleate Ceratobasidium, have been identified as causing damping-off and root dieback diseases in nursery tree seedling stock destined for reforestation (12) and as the agents of disease in a number of other economically important crop plants $(12,25)$. The LFD, therefore, represents a useful tool in the rapid detection of these fungi in naturally infested soil samples.

The usefulness of the device in pathogen detection was illustrated during in vivo tests of field soils naturally infested with

TABLE 2. Absorbance values from plate-trapped antigen enzyme-linked immunosorbent assay tests, with results of lateral flow device (LFD) tests in parentheses ${ }^{\mathrm{a}}$, of amplification solutions from replicate samples of a dilution series prepared using artificially infested chopped-potato soil inoculum

\begin{tabular}{|c|c|c|c|c|c|}
\hline \multirow[b]{2}{*}{ Soil dilution } & \multicolumn{5}{|c|}{ Replicate } \\
\hline & 1 & 2 & 3 & 4 & 5 \\
\hline $1: 2$ & $1.252(+)$ & $1.225(+)$ & $1.217(+)$ & $0.806(+)$ & $1.062(+)$ \\
\hline $1: 4$ & $1.283(+)$ & $1.414(+)$ & $1.532(+)$ & $1.419(+)$ & $1.302(+)$ \\
\hline $1: 8$ & $1.336(+)$ & $1.522(+)$ & $1.316(+)$ & $1.482(+)$ & $1.484(+)$ \\
\hline $1: 16$ & $1.560(+)$ & $1.451(+)$ & $1.541(+)$ & $1.513(+)$ & $1.590(+)$ \\
\hline $1: 32$ & $1.551(+)$ & $1.547(+)$ & $1.540(+)$ & $1.499(+)$ & $1.449(+)$ \\
\hline $1: 64$ & $1.623(+)$ & $1.557(+)$ & $1.592(+)$ & $1.575(+)$ & $1.544(+)$ \\
\hline $1: 128$ & $1.594(+)$ & $1.604(+)$ & $1.606(+)$ & $1.613(+)$ & $1.611(+)$ \\
\hline $1: 256$ & $1.671(+)$ & $0.122(+)$ & $0.600(+)$ & $1.560(+)$ & $1.637(+)$ \\
\hline $1: 512$ & $0.063(+)$ & $0.904(+)$ & $0.043(-)$ & $0.046(-)$ & $1.563(+)$ \\
\hline $1: 1,024$ & $0.046(-)$ & $1.467(+)$ & $0.041(-)$ & $0.046(-)$ & $0.044(-)$ \\
\hline $1: 2,048$ & $0.045(-)$ & $0.044(-)$ & $0.049(-)$ & $0.049(-)$ & $0.041(-)$ \\
\hline $1: 4,096$ & $0.044(-)$ & $0.049(-)$ & $0.042(-)$ & $0.053(-)$ & $0.043(-)$ \\
\hline
\end{tabular}

a Amplification solutions positive (two lines) or negative (single control line) for Rhizoctonia solani antigens in LFD tests. 
$R$. solani. We combined the LFD with previously developed baiting (30) and PCR $(6,16)$ procedures to accurately detect and identify $R$. solani AG3, a group shown in previous studies to be the etiologic agent of stem canker and black scurf diseases of potato (4). Other techniques, notably those employing PCR-based assays, have been developed for the specific detection of $R$. solani AG3 isolates in soil samples $(6,16)$. Bounou et al. (6) used a PCR-based assay, combined with a DNA restriction enzyme, to detect AG3 isolates in naturally infested soil and plant samples. They established that their test would not be suitable for routine detection of the pathogen in soil samples without optimization with respect to its sensitivity, detection limit, and quantification of live fungal biomass and contended that immunological assays represented the main commercial procedure which fulfilled the above criteria. The LFD test described here differs from nucleicacid based procedures in that it detects only live propagules of the pathogen. Consequently, the LFD test was able to identify a field infested with live biomass of $R$. solani AG3, thereby representing a potentially high risk site for potato cultivation.

The specificity of the LFD test was shown by the absence of cross-reactivity with a number of unrelated species that com- monly were recovered from naturally infested soil samples or held in culture collections. It should be noted that, although we used $R$. solani AG3 to illustrate the usefulness of this combined approach to detect a specific $R$. solani AG, the LFD and principles employed in its use are applicable to other crops where diseases have been closely linked to individual Rhizoctonia spp. or AGs. Examples might include basal leaf rot in UK lettuce crops caused by $R$. solani AG4 (30), bare patch of field-grown tulips in the Netherlands caused by $R$. solani AG2-t (22), Rhizoctonia bare patch of cereal seedlings in Australia, South Africa, and the United States caused by $R$. solani AG4 or AG8 (7), damage to a wide range of economically important tree and plant species worldwide caused by binucleate Rhizoctonia AGs $(12,25)$, and degeneration and root rot of strawberries in Canada and the United States caused by $R$. fragariae (37).

A number of $R$. solani AG3 isolates were not detected in LFD tests of surface washings of bait cultures due to overgrowth by faster-growing contaminant species. These false-negative results might be eliminated by incorporating selective inhibitors into the medium to prevent or delay the growth of fast-growing contaminant species. Alternatively, baits could be combined prior to

TABLE 3. Results of combined baiting and lateral flow device (LFD) tests of potato soils naturally infested with Rhizoctonia solani anastomosis group (AG)3

\begin{tabular}{|c|c|c|c|c|c|c|}
\hline \multirow[b]{2}{*}{ Soil, replicate, bait $^{\mathrm{a}}$} & \multicolumn{2}{|c|}{ In visual appraisal } & \multirow[b]{2}{*}{ LFD test $\mathrm{t}^{\mathrm{b}}$} & \multirow[b]{2}{*}{$\mathrm{AG}^{\mathrm{c}}$} & \multirow[b]{2}{*}{ Contaminant fungi $^{\mathrm{d}}$} & \multirow[b]{2}{*}{ Accession no. } \\
\hline & R. solani & Contaminant fungi & & & & \\
\hline \multicolumn{7}{|l|}{ BAN2, A } \\
\hline 1 & + & + & + & 3 & Verticillium coccosporum & AF110531 \\
\hline 3 & - & + & - & - & V. coccosporum & AF110531 \\
\hline 4 & - & + & - & - & Fusarium oxysporum f. sp. vasinfectum & AF332076 \\
\hline 5 & + & + & + & 3 & F. oxysporum f. sp. vasinfectum & AF332076 \\
\hline 9 & + & + & - & ND & V. coccosporum & AF110531 \\
\hline \multicolumn{7}{|l|}{ BAN2, B } \\
\hline 1 & + & + & + & 3 & Mucor racemosus & AF176659 \\
\hline 2 & - & + & - & - & V. coccosporum & AF110531 \\
\hline 3 & + & + & - & 3 & V. coccosporum & AF110531 \\
\hline 4 & - & + & - & - & V. coccosporum & AF110531 \\
\hline \multicolumn{7}{|l|}{ BAN12, A } \\
\hline 1 & + & + & - & 3 & M. circinelloides & AF412288 \\
\hline 2 & - & + & - & - & F. culmorum $^{\mathrm{f}}$ & AF484956 \\
\hline 3 & + & + & + & 3 & V. coccosporum & AF110531 \\
\hline 4 & - & + & - & - & Chaetomium sp. & AJ279468 \\
\hline 5 & - & + & - & - & M. circinelloides ${ }^{\mathrm{f}}$ & AF412288 \\
\hline 6 & + & + & + & ND & M. circinelloides & AF412288 \\
\hline 7 & - & + & - & - & Chaetomium sp. ${ }^{\mathrm{f}}$ & AJ279468 \\
\hline 8 & - & + & - & - & V. coccosporum & AF110531 \\
\hline 9 & - & + & - & - & V. coccosporum & AF110531 \\
\hline \multicolumn{7}{|l|}{ BAN12, B } \\
\hline 1 & + & + & + & ND & M. racemosus $^{\mathrm{f}}$ & AF176659 \\
\hline 2 & + & + & - & ND & F. oxysporum f. sp. vasinfectum ${ }^{\mathrm{f}}$ & AF332076 \\
\hline 3 & - & + & - & - & Trichoderma hamatum ${ }^{\mathrm{f}}$ & AF483594 \\
\hline
\end{tabular}

${ }^{a}$ BAN2 and BAN12 soil samples were taken from a field with a history of stem canker and black scurf diseases of potato in the 2000 and 2001 growing seasons.

${ }^{\mathrm{b}}$ Surface washings positive (two lines) or negative (single control line) for $R$. solani antigens in LFD tests. ND = not determined; $R$. solani isolate could not be recovered for AG determination by polymerase chain reaction (PCR) because of overgrowth by faster-growing contaminant fungus.

c AG of $R$. solani determined in PCR tests using primer sets of Bounou et al. (5) and Lees et al. (12).

${ }^{\mathrm{d}}$ Species identity was predicted based on $>95 \%$ sequence identity of the internal transcribed spacer (ITS) $1-5.8 \mathrm{~S}-\mathrm{ITS} 2$ sequence of contaminant fungi (E-value $=$ $0.0)$ (3) to species recorded in GenBank.

e GenBank accession number of ITS sequence of species showing highest similarity to contaminant fungus.

${ }^{\mathrm{f}}$ ITS sequences of isolates submitted to GenBank; accession numbers shown in Table 1. 
testing, a procedure that was used in the detection of $R$. solani AG3 in soil using a combined baiting and PCR test (16). Notwithstanding this, the LFD has been used extensively in ongoing tests of naturally infested potato soils, with consistent agreement between $R$. solani AG3 detection and black scurf occurrence (C. R. Thornton, unpublished data).

Further studies are needed to examine the accuracy of the LFD in detecting different $R$. solani AGs in naturally infested soils using this combined technique. Nevertheless, we believe that the LFD could provide a rapid, simple, and relatively inexpensive means of detecting $R$. solani and certain other related pathogenic species in soil and that, when combined with other methods such as PCR, it could provide an additional aid in the accurate diagnosis of these pathogens in soil. We envision that the technology could be used by untrained personnel with limited immunological, mycological, or plant pathological expertise, but who have access to basic microbiological facilities. Further development and refinement of the LFD test for use by the wider scientific community is currently underway.

\section{ACKNOWLEDGMENTS}

This work was funded in part by a University of Exeter Research Fellowship held by C. R. Thornton and in part by a UK Government Department of Trade and Industry Smart I award made to Eco Diagnostics Ltd., to whom we are grateful. The work was completed during the tenure of a Biotechnology and Biological Sciences Research Council BIRE Initiative grant (BRE13618) awarded to C. R. Thornton and N. J. Talbot. We thank N. Tongue for technical assistance in the ITS sequencing of fungi. The lateral flow device is the sole property of Eco Diagnostics Ltd. and Exeter University.

\section{LITERATURE CITED}

1. Adams, G. C. 1988. Thanatephorus cucumeris (Rhizoctonia solani), a species complex of wide host range. Pages 535-552 in: Advances in Plant Pathology. Vol. 6. Genetics of Plant Pathogenic Fungi. D. S. Ingram, and P. H. Williams, eds. Academic Press, London.

2. Anderson, N. A. 1982. The genetics and pathology of Rhizoctonia solani. Annu. Rev. Phytopathol. 20:329-347.

3. Altschul, S. F., Madden, T. L., Schaffer, A. A., Zhang, Z., Miller, W., and Lipman, D. J. 1997. Gapped BLAST and PSI-BLAST: A new generation of protein database programs. Nucleic Acids Res. 25:3389-3402.

4. Bandy, B. P., Leach, S., and Tavantzis, S. M. 1988. Anastomosis group 3 is the major cause of Rhizoctonia disease of potato in Maine. Plant Dis. 72:596-598.

5. Bird, C. B., Miller, R. L., and Miller, B. M. 1999. Reveal for Salmonella test system. J. AOAC Int. 82:625-633.

6. Bounou, S., Jabaji-Hare, S. H., Hogue, R., and Charest, P. M. 1999. Polymerase chain reaction based assay for specific detection of Rhizoctonia solani AG-3 isolates. Mycol. Res. 103:1-8.

7. Brisbane, P. G., Neate, S. M., Pankhurst, C. E., Scott, N. S., and Thomas, M. R. 1995. Sequence-tagged site markers to identify Rhizoctonia solani AG4 or 8 infecting wheat in South Australia. Phytopathology 85:14231427.

8. Danks, C., and Barker, I. 2000. On-site detection of plant pathogens using lateral-flow devices. OEPP/EPPO Bull. 30:421-426.

9. Dewey, F. M. 1992. Detection of plant invading fungi by monoclonal antibodies. Pages 47-62 in: Techniques for the Rapid Detection of Plant Pathogens. J. M. Duncan and L. Torrance, eds. Blackwell Scientific Publications, Oxford.

10. Dewey, F. M., and Thornton, C. R. 1995. Fungal immunodiagnostics in plant agriculture. Pages 151-170 in: New Diagnostics in Crop Sciences. Biotechnology in Agriculture Series 13. J. H. Skerrit and R. Appels, eds. CABI, UK

11. Dewey, F. M., Thornton, C. R., and Gilligan, C. A. 1997. Use of monoclonal antibodies to detect, quantify and visualize fungi in soil. Pages 275-308 in: Advances in Botanical Research Incorporating Advances in Plant Pathology vol. 24. Academic Press, San Diego, CA.

12. Gronberg, H., Paulin, L., and Sen, R. 2003. ITS probe development for specific detection of Rhizoctonia spp. and Suillus bovinus based on Southern blot and liquid hybridization-fragment length polymorphism. Mycol. Res. 107:428-438.
13. Husain, S. S., and McKeen, W. E. 1963. Rhizoctonia fragariae sp. nov. in relation to strawberry degeneration in southwestern Ontario. Phytopathology 53:532-540.

14. Ketema, F., Zeh, C., Edelman, D. C., Saville, R., and Constantine, N. T. 2001. Assessment of the performance of a rapid, lateral flow assay for the detection of antibodies to HIV. J. Acquir. Immune Defic. Syndr. 27:63-70.

15. Ko, W.-H., and Hora, F. K. 1971. A selective medium for quantitative determination of Rhizoctonia solani in soil. Phytopathology 61:707-710.

16. Lees, A. K., Cullen, D. W., Sullivan, L., and Nicolson, M. J. 2002. Development of conventional and quantitative real-time PCR assays for the detection and identification of Rhizoctonia solani AG-3 in potato and soil. Plant Pathol. 51:293-302.

17. Marck, C. 1989. DNA Strider 1.1. Service de Biochemie. Department de Biologie, Institute de Reserche Fondimentale, CEA, France.

18. Miller, S. A., Rittenburg, J. H., Petersen, F. P., and Grothaus, G. D. 1992. From the research bench to the market place: development of commercial diagnostic kits. Pages 208-221 in: Techniques for the Rapid Detection of Plant Pathogens. J. M. Duncan and L. Torrance, eds. Blackwell Scientific Publications, Oxford.

19. Parmeter, J. R. 1970. Rhizoctonia solani, Biology and Pathology. University of California Press, Berkeley.

20. Ridout, M. S., and Welham, S. J. 1993. Procedure dilution. In: Genstat 5: Procedure Library Manual, Release 3[1]. R. W. Payne, G. M. Arnold, and G. W. Morgan, eds. Clarendon Press, Oxford.

21. Salazar, O., Julian, M. C., and Rubio, V. 2000. Primers based on specific rDNA-ITS sequences for PCR detection of Rhizoctonia solani, $R$. solani AG2 subgroups and ecological types, and binucleate Rhizoctonia. Mycol. Res. 104:281-285.

22. Schneider, J. H. M., Schilder, M. T., and Dijst, G. 1997. Characterization of Rhizoctonia solani AG 2 causing bare patch in field grown tulips in the Netherlands. Eur. J. Plant Pathol. 103:265-279.

23. Shyu, R. H., Shyu, H. F., Liu, H. W., and Tang, S. S. 2002. Colloidal gold-based immunochromatographic assay for detection of ricin. Toxicon 40:255-258.

24. Smits, H. L., Eapen, C. K., Sugathan, S., Kuriakose, M., Gasem, M. H., Yersin, C., Sasaki, D., Pujianto, B., Vestering, M., Abdoel, T. H., and Gussenhoven, G. C. 2001. Lateral-flow assay for rapid serodiagnosis of human leptospirosis. Clin. Diagn. Lab. Immunol. 8:166-169.

25. Sneh, B., Burpee, L., and Ogoshi, A. 1991. Identification of Rhizoctonia Species. The American Phytopathological Society, St. Paul, MN.

26. Sreenivasiprasad, S., Sharada, K., Brown, A. E., and Mills, P. R. 1996. PCR-based detection of Colletotrichum acutatum on strawberry. Plant Pathol. 45:650-655.

27. Sutula, C. L., Gillett, J. M., Morrissey, S. M., and Ramsdell, D. C. 1986. Interpreting ELISA data and establishing the positive-negative threshold. Plant Dis. 90:722-726.

28. Thornton, C. R. 2001. Immunological methods for fungi. Pages 227-257 in: Molecular and Cellular Biology of Filamentous Fungi: A Practical Approach. N. J. Talbot, ed. University Press, Oxford.

29. Thornton, C. R., Dewey, F. M., and Gilligan, C. A. 1993. Development of monoclonal antibody-based immunological assays for the detection of live propagules of Rhizoctonia solani in the soil. Plant Pathol. 42:763-773.

30. Thornton, C. R., O'Neill, T. M., Hilton, G., and Gilligan, C. A. 1999. Detection and recovery of Rhizoctonia solani in naturally infested glasshouse soils using a combined baiting, double monoclonal antibody ELISA. Plant Pathol. 48:627-634.

31. Trujillo, E. E., Cavin, C. A., Aragaki, M., and Yoshimura, M. A. 1987. Ethanol-potassium nitrate medium for enumerating Rhizoctonia solanilike fungi from soil. Plant Dis. 71:1098-1100.

32. Verheijen, R., Osswald, I. K., Dietrich, R., and Haasnoot, W. 2000. Development of a one step strip test for the detection of (dihydro)streptomycin residues in raw milk. Food Agric. Immunol. 12:31-40.

33. Verheijen, R., Stouten, P., Cazemier, G., and Haasnoot, W. 1998. Development of a one step strip test for the detection of sulfadimidine residues. Analyst 123:2437-2441.

34. Vincelli, P. C., and Beaupre, C. M.-S. 1989. Comparison of media for isolating Rhizoctonia solani from soil. Plant Dis. 73:1014-1017.

35. Whisson, D. L., Herdina, and Francis, L. 1995. Detection of Rhizoctonia solani AG-8 in soil using a specific DNA probe. Mycol. Res. 99:12991302.

36. White, T. J., Bruns, T., Lees, S., and Taylor, J. 1990. Amplification and direct sequencing of fungal ribosomal RNA genes for phylogenetics. Pages 315-322 in: PCR Protocols: A Guide to Methods and Applications. M. A. Innis, D. H. Gelfand, J. J. Sninsky, and T. J. White, eds. Academic Press, San Diego, CA.

37. Wilhelm, S., Nelson, P. E., Thomas, H. E., and Johnson, H. 1972. Pathology of strawberry root rot caused by Ceratobasidium species. Phytopathology 62:700-705. 